\title{
Breast Cancer pN1 TNM Finding v6
}

National Cancer Institute

\section{Source}

National Cancer Institute. Breast Cancer pN1 TNM Finding v6. NCI Thesaurus. Code C48996.

Breast cancer with metastasis to 1 to 3 axillary lymph nodes, and/or internal mammary nodes with microscopic disease detected by sentinel lymph node dissection but not clinically apparent. (from AJCC 6th Ed.) 